\title{
The Economic Crisis in the Mining Sector - Miners Perspective
}

\author{
Sabina Irimie ${ }^{1}$, Luise Zeininger ${ }^{2}$ and Mircea Mihai ${ }^{3}$ \\ ${ }^{1}$ University of Petroșani, Petroșani, Romania, sabina.irimie@gmail.com \\ ${ }^{2,3}$ The Bucharest Academy of Economic Studies, Romania
}

Correspondence should be addressed to: Sabina Irimie; sabina.irimie@gmail.com

Received date: 10 September 2015; Accepted date: 12 January 2016; Published date: 23 February 2016

Academic Editor: Elena Otilia P. Manta

Copyright (C) 2016. Sabina Irimie, Luise Zeininger and Mircea Mihai. Distributed under Creative Commons CC-BY 4.0

\begin{abstract}
The present paper's objective is to assess the perceptions and reactions of the employees' of Jiu Valley mine (Romania) related to the current crisis. For this, an interview protocol as work instrument was applied which contained 17 opinion and factual questions required for the structuring of the research area. The findings illustrate the way the mining industry workers were impacted by the effects of the financial, economical-social and moral crisis occurred after 2007. In fact, the impact overlaid the effects of the labor system's crisis in the Romanian mining sector existing for over 20 years. There were identified those who considered themselves affected by this crisis, the solutions they used or were going to use in the future in order to overcome it, what was the institutional responsible for taking the measures to overcome the crisis. The hypothesis of the paper was confirmed: that those who consider themselves affected by the crisis are more afraid for their jobs than the others. The job - as an economical and social safety element - affords them the psychological comfort that will enable them to overcome the crisis. But in the Romanian mining industry, due to the closure of mines, jobs will be lost as a synergic effect and, especially, as a result of the lack of government involvement.
\end{abstract}

Keywords: crisis, mining sector, mining restructuring, income

\section{Introduction}

The 1972 energy crisis continued with a global resources crisis after 2008 that extended to many other society areas: banking, financial, economical, social, moral. Natural resources of Romania - oil, gases, gold, cooper, led, industrial minerals, wood, coal - were destroyed by both interventions such as: under sales - selling prices being hugely undervalued, lack of beneficiaries, mass layoffs and non-interventions such as: lack of investments, lack of management, bankruptcy. All these actions, done highly inefficiently, really chaotically, even so some that were supported by feasibility studies lacked a coherent national or sectorial strategy. The result was "a deliberate robbery of country's natural resources" (Stegar \& Krausz, 2011) and decline of all 
the energetic sector and horizontal industry developed till 1989 as a real cluster.. The mineral resource our paper is looking at is the Romanian coal, a resource with such a negative political and social impact after the 1990's "mineriade" events.

Historically speaking, mining in Valea Jiului was at its peak during the communist period and started to decline after 1990 when the market economy transition begun. Via a massive restructuring / reorganization ongoing process, we witness a dramatic mining sector crisis with perspectives to be terminated by 2018. During the last 25 years, the restructuring process meant that either assets and staff were transferred or some units were liquidated such as: The Valea Jiului Mining complex, 1990; Hard Coal Regia Autonoma, 1991, National Company of Hard Coal - Petrosani - 1998, National Company Of Hard Coal - 2012, The Valea Jiului Mining Liquidation National Society 2012, The Energetic Complex Hunedoara2013). Others were stopped (Lonea Pilier Mining, 1994; Câmpu lui Neag and Petrila Sud Mining, 1999; Dâlja Mining, 2003; Valea de Brazi Mining, 2004; Aninoasa Mining, 2006) and some were transformed into independent companies - by outsourcing: (Banat mining, 1998; The IT center Petroşani, 1998; The administrative Unit of housing and Cantines Valea Jiului, 1998; The Technical and Technological Design Unit, 1998).

The organisational structures still working today to extract, prepare and produce electrical and thermic energy are:

- The Valea Jiului Mining Liquidation National Society - including Petrila, Paroșeni and Uricani minings;

- The Hunedoara Energetic Complex including: Lonea, Livezeni, Vulcan, Lupeni minings, The Mining Salvation Station and the Coal preparation station Valea Jiului.

The staff number working in Valea Jiului mining sector in the period 1990-2015 has constantly decreased up to a dramatic downsize in 1997 (from 55,000 employees in 1990 to 45,647 employees in 1996 and up to 24,258 employees in 1997). Ever since, the decrease continues but at a slower pace of several hundred of employees per year. Today, there are only 7,034 employees for both the two entities still operational in Valea Jiului but a new lot of 489 workers is expected to be laid out (Bodea, Bozdog \& Burdea, 2013).

Ever since its beginning, mining in Valea Jiului faced specific technical issues that turned hard coal mining into a difficult, inefficient, high risk activity with very specific hazards: thin and inclined coal layers, many layers faults, hard steril, metan, water. We could add to these natural hazards the work hazards: explosion risk, physical, visual, hearing over strung, back affection due to high mass manipulation, cave in risk topped by, after 1990, job insecurity (Marica, Irimie \& Băleanu, 2015). Miners were forced to deal with top of hard work at work with increased responsibilities, more complex task due to less staffing, higher physical stress and less money to cover their family needs as well as job volatility.

The aim of the present paper is to understand the perceptions and reactions to the crisis of ValeaJiului miners.

\section{Research Methodology and Investigation Area}

The present research field phase was conducted at Uricani mine, beginning of 2015 and is part of a larger research work on all the mines in the area. The main research instrument was an interviewprotocol elaborated specifically for this purpose. Interview questions were focused on the present economical-financial crisis looking after aspects such as: crisis impact on subjects, their opinion on individual and institutional solutions to overcome the crisis, mining industry perspectives etc.

The interview protocol has 17 questions and the research conducted interviews with 389 employees of Uricani mine. The average duration of an interview was of about 20 minutes and implied for some interviews that the person interviewed wrote down their answers themselves while the interviewer was just offering support. This way, we got more subjects to answer (interviews were conducted mostly at the 
end of the shifts) and collected valuable information but because of the inherent rush to go home after work some answers were missing when they would fill in by themselves the interview.

The research used both quantitative and qualitative methods (documents analysis, observation, inquiry) and the results were processed primary and secondary using SPSS software and manually.

Next we will provide some of the sociodemographic characteristics of the investigated sample-population.
Considering the first criterion "gender", the percentage of male respondents is overwhelming over the female respondents, consistent with the organisation's gender staff structure, as shown in figure 1 . From the age point of view, the subjects could be divided in 4 big categories: under 25; between 26 and 35; between 36 and 50 and over 50 years old. The largest category is the one between 36 and 50 years old; it indicates that mining is done with mostly next to retirement employees, young people not being attracted by this field, nor having opportunities to get hired. The structure of the sample population by age is represented in figure 2.

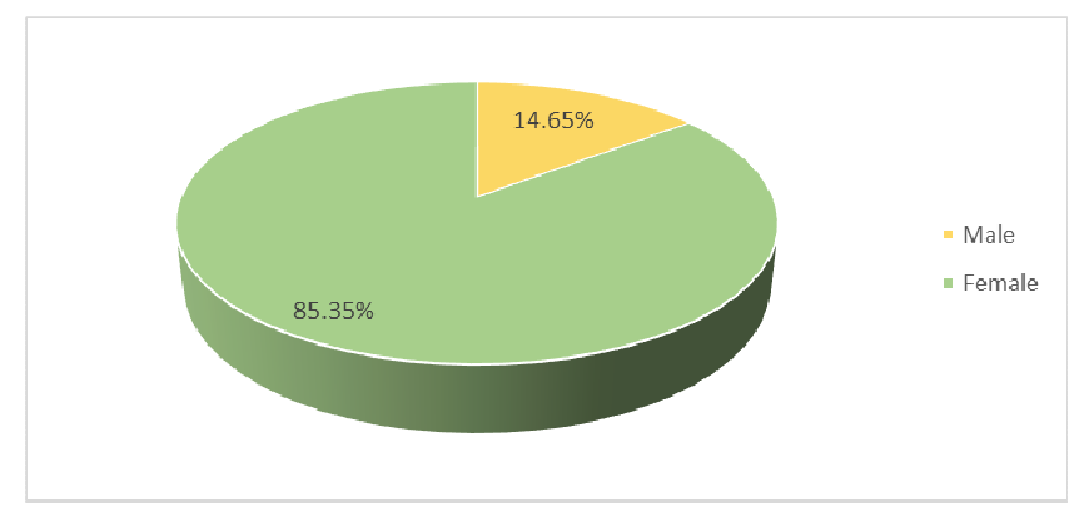

Source: authors

Figure 1: Respondents' structure - gender criteria

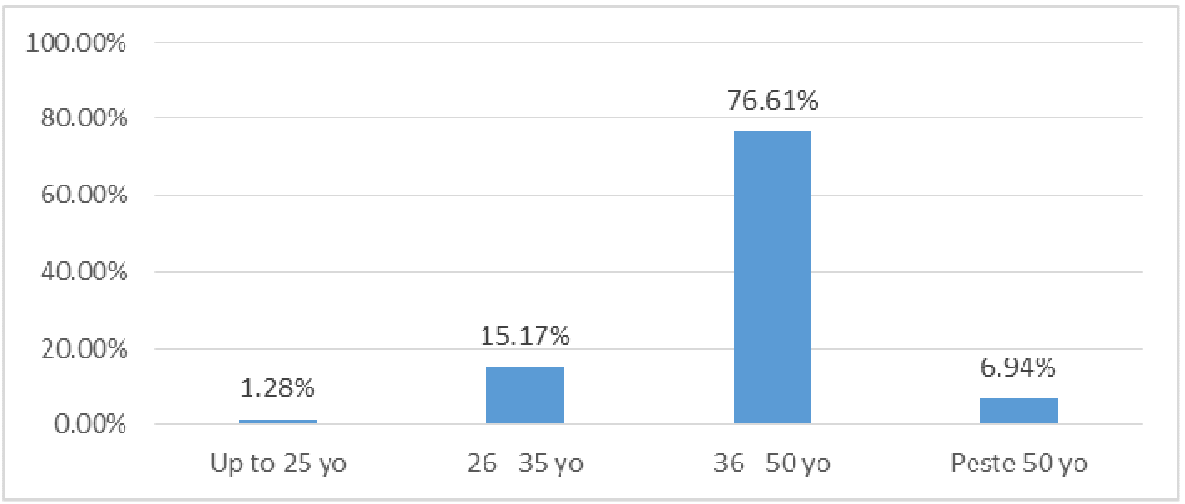

Source: authors

Figure 2: Respondents' structure - age criteria

Education criteria: based on their declarations, no uneducated person was among the interview ones, the minimum declared being as 8th grade graduate. The structure is represented in figure 3. 


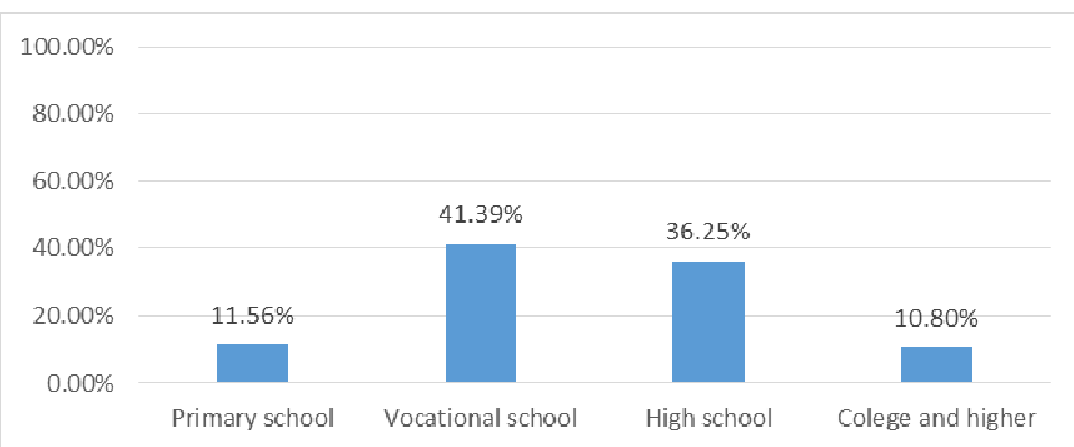

Source: authors

Figure 3: Education criteria- respondents' structure

Exacerbated by the economic crisis that is still hurting Romanian economy, problems generated by insufficient income are a major issue. Taking this effect into account two of our interview questions addressed this aspect. The results of one of them - related to average monthly income per family is shown in figure 4.

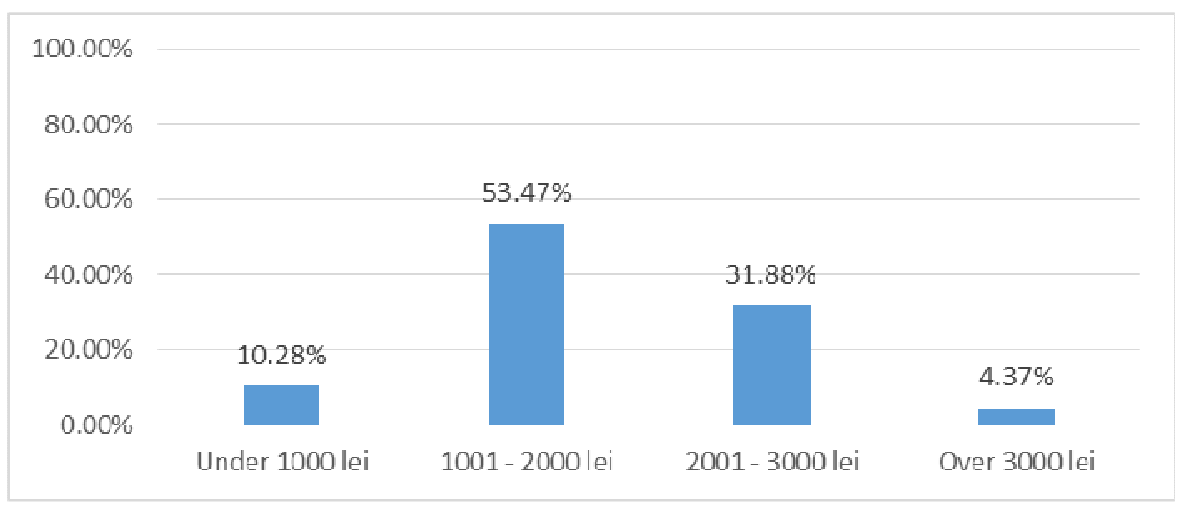

Source: authors

Figure 4: Average monthly family income structure

The second question related to income will be addressed in the next part of this paper.
Residence criteria. Most of the respondents, about $60 \%$, live in Uricani. The rest of $40 \%$ live in the neighbouring cities. The detailed results are presented below in figure 5 .

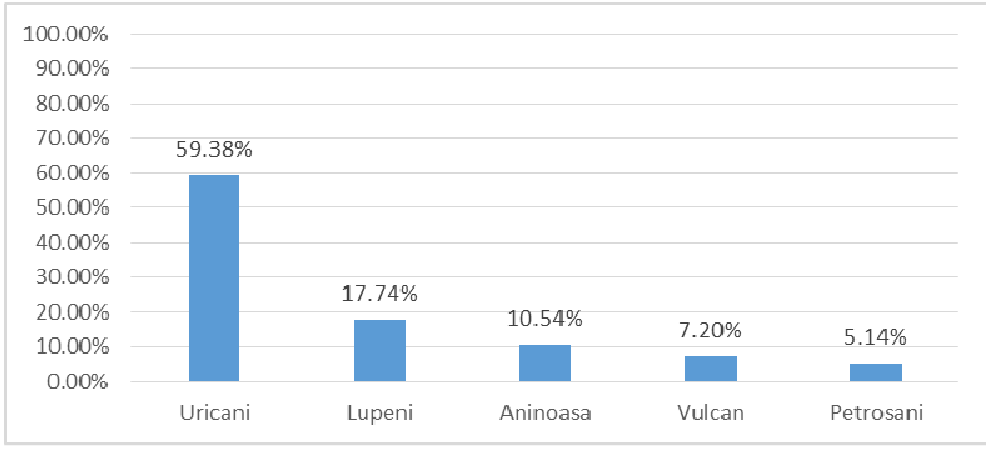

Source: authors

Figure 5: Residence city - criteria structure 
Housing is mostly represented by privately owned apartments, less than $10 \%$ of the respondents have answered that they live in rented apartments or indicated they live with other relatives: parents, in-laws (data obtained from correlation tables). Marital status criteria. An overwhelming majority, over $84 \%$ of the respondents are married with a little over $15 \%$ single, divorced, widowhood, in a relationship, as shown below in figure 6.

The last analyzed criterion was the duration of their service measured through the number of years they worked. We could notice that most of them have worked for more than 20 years. Based on the answers, the following structure (figure 7) was obtained:

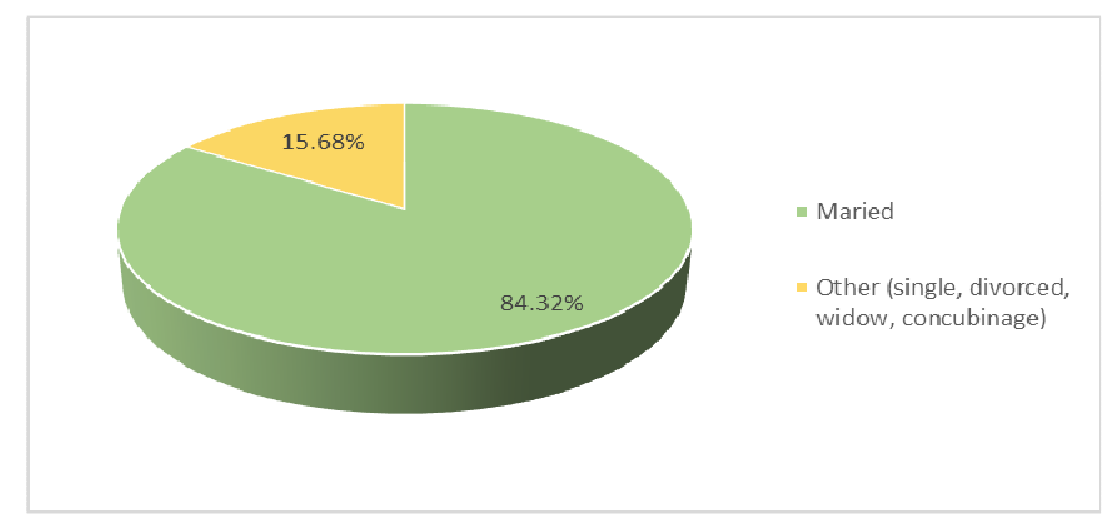

Source: authors

Figure 6: Marital status - criteria; respondents' structure

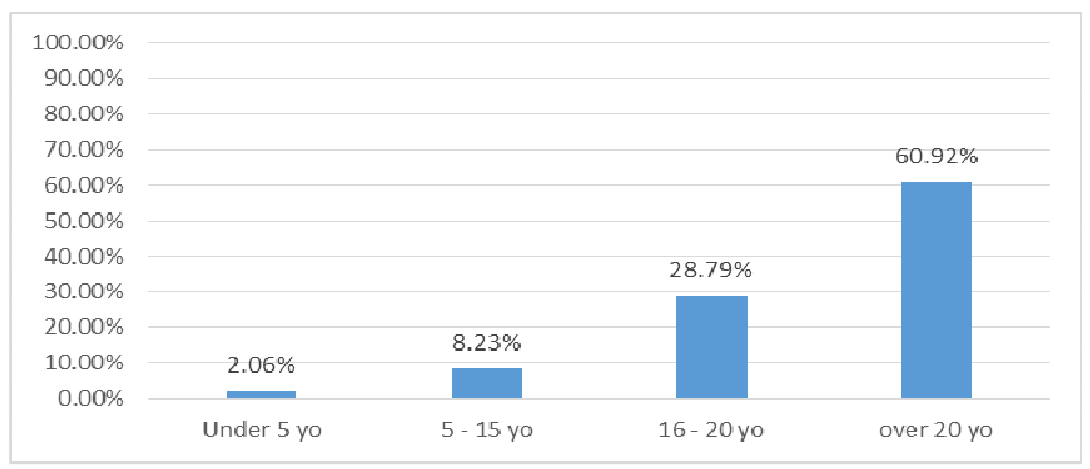

Source: authors

Figure 7: Length of service criteria- respondents' structure

\section{Results Analysis and Data Interpretation}

The economic difficulties Romania is struggling to cope with and the unsuccessful attempts of the Romanian Government to overcome it marked directly or indirectly the whole population. Asked if the existing economical-financial crisis affected their personal and/or family life, most of the respondents answered affirmatively with only a very small percentage not being affected as presented in figure 8 . 


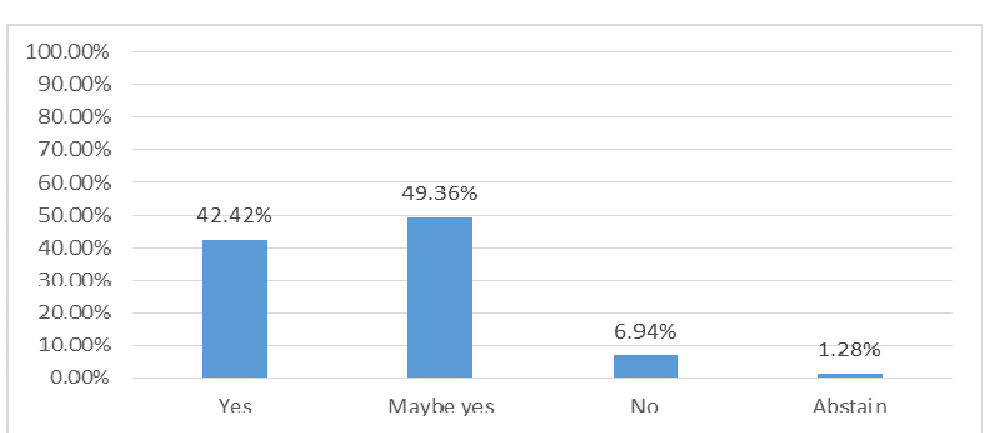

Figure 8: The degree to which personal and familial life was affected by the crisis Source: authors

According to our data analysis, presented below in table 1 , the respondents mostly affected by the crisis are the ones that:

- consider their job at danger due to the intentions of restructuring announced by their employer the National Hard Coal Company short N.H.C.C. (generating not only decrease of income but possibly loss of income);
- have a low income of below 1000 lei/month;

- the pessimists that consider the crisis will continue for 5 years, form now on and over;

- the less educated - only graduates of 8th grade;

- females;

- aged over 50 .

Table 1: Correlation between the question regarding the effects of crisis over personal and familial life with other variables

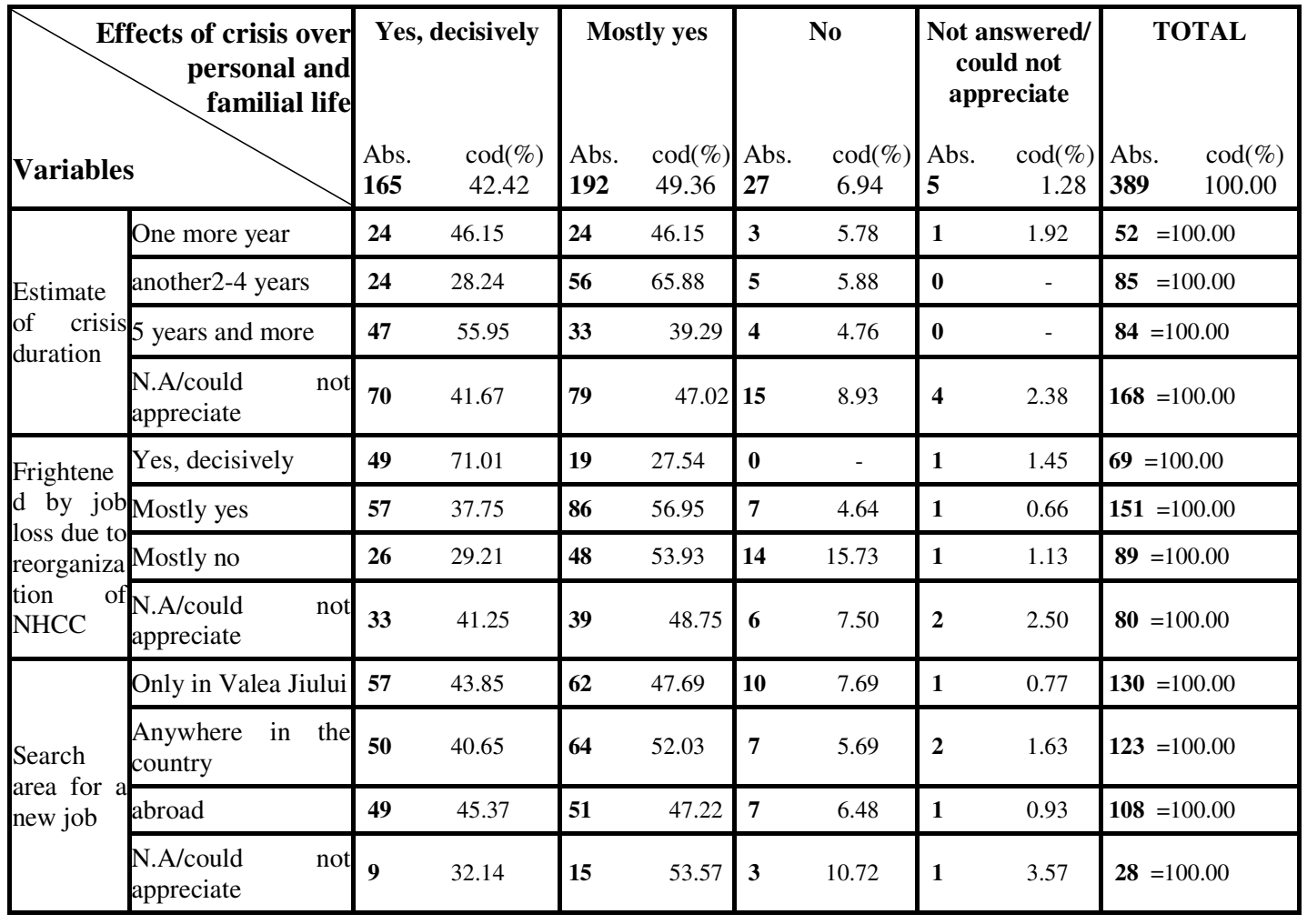




\begin{tabular}{|c|c|c|c|c|c|c|c|c|c|c|}
\hline \multirow{4}{*}{$\begin{array}{l}\text { Family } \\
\text { income }\end{array}$} & Less than 1000 lei & 25 & 62.50 & 13 & 32.50 & 2 & 5.00 & $\mathbf{0}$ & - & $\mathbf{4 0}=100.00$ \\
\hline & 1001-2000 lei & 95 & 45.67 & 96 & 46.15 & 15 & 7.22 & 2 & 0.96 & $\mathbf{2 0 8}=100.00$ \\
\hline & 2001-3000 lei & 41 & 33.06 & 74 & 59.68 & 8 & 6.45 & 1 & 0.81 & $124=100.00$ \\
\hline & over 3000 lei & 4 & 23.53 & 9 & 52.95 & 2 & 11.76 & 2 & 11.76 & $\mathbf{1 7}=100.00$ \\
\hline \multirow{2}{*}{ Gender } & male & 135 & 40.66 & 168 & 50.61 & 26 & 7.83 & 3 & 0.90 & $\mathbf{3 3 2}=100.00$ \\
\hline & female & 30 & 52.63 & 24 & 42.10 & 1 & 1.76 & 2 & 3.51 & $\mathbf{5 7}=100.00$ \\
\hline \multirow{4}{*}{ Age } & $\begin{array}{l}\text { Less than } 25 \text { and } \\
\text { including }\end{array}$ & 2 & 40.00 & 1 & 20.00 & 1 & 20.00 & 1 & 20.00 & $\mathbf{5}=100.00$ \\
\hline & 26-35 years & 25 & 42.37 & 30 & 50.85 & 4 & 6.78 & $\mathbf{0}$ & - & $\mathbf{5 9}=100.00$ \\
\hline & $36-50$ years & 124 & 41.61 & 151 & 50.67 & 20 & 6.71 & 3 & 1.01 & $298=100.00$ \\
\hline & over 50 years & 14 & 51.85 & 10 & 37.04 & 2 & 7.41 & 1 & 3.70 & $27=100.00$ \\
\hline \multirow{4}{*}{ Education } & Middle school & 24 & 53.32 & 17 & 37.78 & 2 & 4.45 & 2 & 4.45 & $45=100.00$ \\
\hline & Vocational school & 67 & 41.62 & 83 & 51.55 & 11 & 6.83 & $\mathbf{0}$ & - & $161=100.00$ \\
\hline & High school & 56 & 39.72 & 71 & 50.35 & 11 & 7.80 & 3 & 2.13 & $141=100.00$ \\
\hline & University/college & 18 & 42.86 & 21 & 50.00 & 3 & 7.14 & $\mathbf{0}$ & & $42=100.00$ \\
\hline
\end{tabular}

Source: authors

Following the same analysis, we could notice that the respondents affected on a moderate rate by the crisis have the following characteristics:

- consider the crisis will continue for the next 2-4 years;

- feel their job threatened by the reorganisation of N.H.C.C.;

- not sure where they would look for a new job;

- income between 2001-3000 lei/month;
- age between 26-50 years old;

- vocational school graduates;

- males.

Most of the respondents feeling threatened by the crisis have a subjective appreciation of their family income. Therefore, a large number of respondents consider their income insufficient, about a third think their income is barely enough and only a selected few respondents rate it as good/very good. Subjective analysis of average monthly family income is shown below in figure 9 .

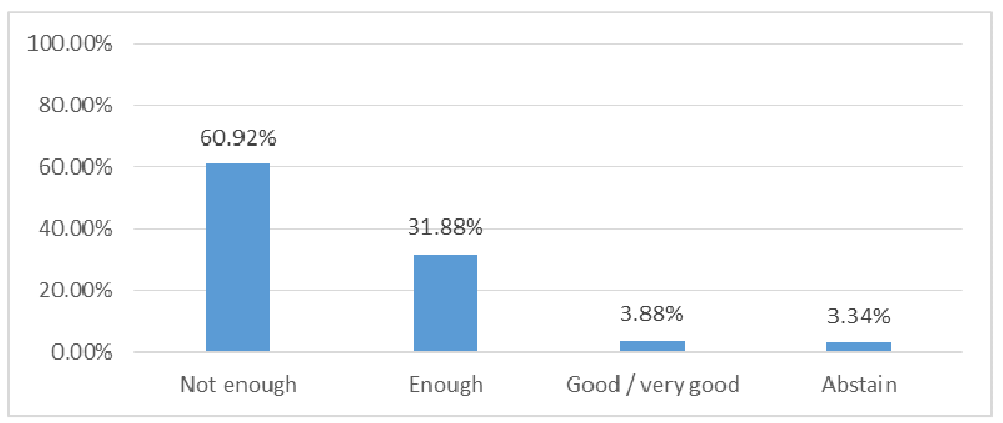

Figure 9: Subjective analysis of average monthly family income Source: authors 
More than half of the respondents could not/did not want to make any prediction on when the crisis would end, about 20\% indicated over 5 years and 2-4 years and the rest, more optimistic, estimate the duration of the crisis to one year. The results are presented in figure 10 .

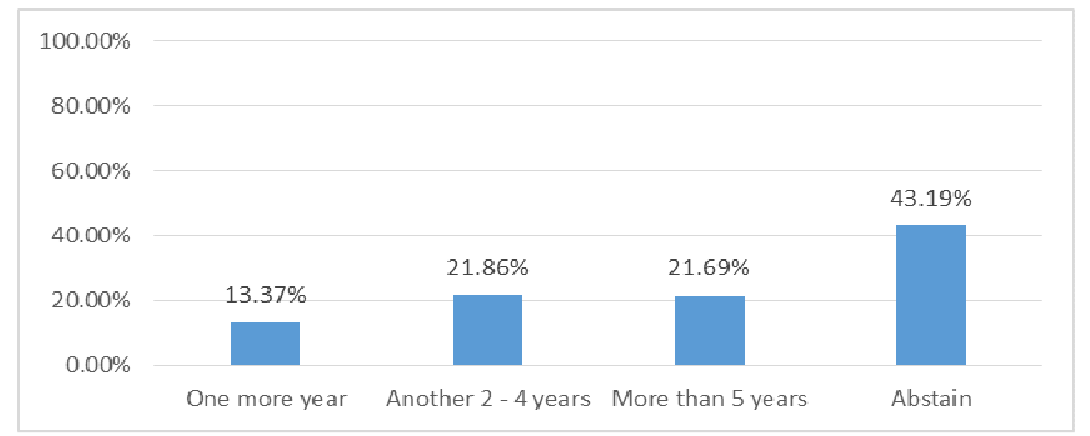

Source: authors

Figure 10: Crisis duration estimate

Our data analysis correlating the estimations on crisis duration and the other variables considered (see table 2 below) reveals that the ones who consider that the crisis will continue for one more year are the ones:
- who do not feel their job is threatened by the possibility of NHCC reorganization;

- over 50 years old.

Table 2: Correlation between crisis duration estimate and other variables

\begin{tabular}{|c|c|c|c|c|c|c|c|c|c|c|}
\hline \multirow{2}{*}{\multicolumn{2}{|c|}{ Variables }} & \multirow{2}{*}{\multicolumn{2}{|c|}{$\begin{array}{l}1 \text { more year } \\
\\
\text { Abs. } \operatorname{cod}(\%) \\
\mathbf{5 2} \quad 13.37\end{array}$}} & \multirow{2}{*}{\multicolumn{2}{|c|}{ 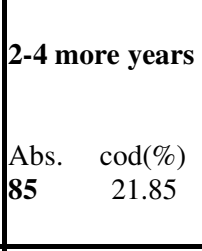 }} & \multicolumn{2}{|c|}{$\begin{array}{c}5 \text { years and } \\
\text { more }\end{array}$} & \multicolumn{2}{|c|}{$\begin{array}{l}\text { N.A./could not } \\
\text { appreciate }\end{array}$} & \multirow{2}{*}{ 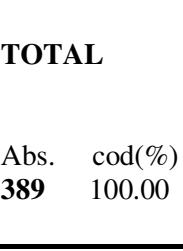 } \\
\hline & & & & & & $\begin{array}{r}\text { Abs. } \\
\mathbf{8 4}\end{array}$ & $\begin{array}{r}\operatorname{cod}(\%) \\
21.59\end{array}$ & $\begin{array}{l}\text { Abs. } \\
168\end{array}$ & $\begin{array}{c}\operatorname{cod}(\%) \\
43.19\end{array}$ & \\
\hline \multirow{4}{*}{$\begin{array}{l}\text { Estimate of } \\
\text { crisis } \\
\text { duration }\end{array}$} & One more year & 24 & 14.55 & 24 & 14.55 & 47 & 28.48 & 70 & 42.42 & $\mathbf{1 6 5}=100.00$ \\
\hline & $\begin{array}{l}\text { another2-4 } \\
\text { years }\end{array}$ & 24 & 12.50 & 56 & 29.17 & 33 & 17.19 & 79 & 41.14 & $192=100.00$ \\
\hline & $\begin{array}{l}5 \text { years and } \\
\text { more }\end{array}$ & 3 & 11.11 & 5 & 18.52 & 4 & 14.81 & 15 & 55.56 & $27=100.00$ \\
\hline & $\begin{array}{l}\text { N.A/could not } \\
\text { appreciate }\end{array}$ & 1 & 20.00 & $\mathbf{0}$ & - & $\mathbf{0}$ & - & 4 & 80.00 & $5=100.00$ \\
\hline \multirow{4}{*}{$\begin{array}{l}\text { Frightened } \\
\text { by job loss } \\
\text { due to } \\
\text { reorganizatio } \\
\mathrm{n} \text { of NHCC }\end{array}$} & Yes. decisively & 6 & 8.70 & 12 & 17.39 & 16 & 23.19 & 35 & 50.72 & $69=100.00$ \\
\hline & Mostly yes & 17 & 11.25 & 38 & 25.17 & 39 & 5.83 & 57 & 37.75 & $151=100.00$ \\
\hline & Mostly no & 19 & 21.35 & 19 & 21.35 & 16 & 17.98 & 35 & 39.32 & $89=100.00$ \\
\hline & $\begin{array}{l}\text { N.A/could not } \\
\text { appreciate }\end{array}$ & 10 & 20.00 & 16 & 20.00 & 13 & 16.25 & 41 & 51.25 & $\mathbf{8 0}=100.00$ \\
\hline \multirow{4}{*}{$\begin{array}{c}\text { Search area } \\
\text { for a new job }\end{array}$} & $\begin{array}{l}\text { Only in Valea } \\
\text { Jiului }\end{array}$ & 17 & 13.08 & 39 & 30.00 & 20 & 15.38 & 54 & 41.54 & $\mathbf{1 3 0}=100.00$ \\
\hline & $\begin{array}{l}\text { Anywhere in } \\
\text { the country }\end{array}$ & 20 & 16.26 & 22 & 17.89 & 35 & 28.45 & 46 & 37.40 & $123=100.00$ \\
\hline & abroad & 11 & 10.18 & 22 & 20.37 & 27 & 25.00 & 48 & 44.45 & $\mathbf{1 0 8}=100.00$ \\
\hline & N.A/could not & 4 & 14.29 & 2 & 7.14 & 2 & 7.14 & 20 & 71.43 & $\mathbf{2 8}=100.00$ \\
\hline
\end{tabular}




\begin{tabular}{|c|c|c|c|c|c|c|c|c|c|c|}
\hline & appreciate & & & & & & & & & \\
\hline \multirow{2}{*}{ Gender } & Male & 51 & 15.36 & 68 & 20.48 & 73 & 21.99 & 140 & 42.17 & $332=100.00$ \\
\hline & female & 1 & 1.75 & 17 & 29.82 & 11 & 19.30 & 28 & 49.13 & $\mathbf{5 7}=100.00$ \\
\hline \multirow{4}{*}{ Age } & $\begin{array}{l}\text { Less than } 25 \\
\text { and including }\end{array}$ & $\mathbf{0}$ & - & $\mathbf{0}$ & - & 1 & 20.00 & 4 & 80.00 & $5=100.00$ \\
\hline & 26-35 years & 6 & 10.17 & 21 & 35.59 & 12 & 20.34 & 20 & 33.90 & $\mathbf{5 9}=100.00$ \\
\hline & $36-50$ years & 40 & 13.42 & 55 & 18.46 & 67 & 22.48 & 136 & 45.64 & $\mathbf{2 9 8}=100.00$ \\
\hline & over 50 years & 6 & 22.22 & 9 & 33.33 & 4 & 14.82 & 8 & 29.63 & $27=100.00$ \\
\hline \multirow{4}{*}{ Education } & $\begin{array}{l}\text { Middle } \\
\text { school }\end{array}$ & 7 & 15.56 & 9 & 20.00 & 9 & 20.00 & 20 & 44.44 & $45=100.00$ \\
\hline & $\begin{array}{l}\text { Vocational } \\
\text { school }\end{array}$ & 20 & 12.42 & 31 & 19.26 & 36 & 22.36 & 74 & 45.96 & $\mathbf{1 6 1}=100.00$ \\
\hline & High school & 21 & 14.89 & 29 & 20.57 & 30 & 21.28 & 61 & 43.26 & $\mathbf{1 4 1}=100.00$ \\
\hline & $\begin{array}{l}\text { University/co } \\
\text { llege }\end{array}$ & 4 & 9.52 & 16 & 38.09 & 9 & 21.43 & 13 & 30.96 & $\mathbf{4 2}=100.00$ \\
\hline
\end{tabular}

Source: authors

The analysis also indicates (see table 2) that people who consider the crisis will continue for 2-4 more years have following profile:

- they would only look for/accept a new job in Valea Jiului;

- graduated from college/university;

- age between 26-35 years old.

Similarly, the respondents that indicated more than 5 years till the end of the crisis are:

- substantially affected by the existing crisis;

- willing to look for/accept a job anywhere else in Romania or abroad if they would lose the present job.

Also, as presented in table 2, the ones reluctant to answer are people who:

- are not sure whether they would look for/accept another job if they would lose the present one;
- declared they were not affected by the crisis so far;

- aged between 36-50 years old;

- are females.

Analysis of the answers to "what solution are they going to use to overcome crisis effects?" is gaining even more importance due to the large number of respondents that declared they are already affected by the crisis. Each respondent could pick one or more solutions, in total our study recorded 519 choices coming from 389 respondents. More than half are related to having more than one job, about $20 \%$ are about using personal savings, $10 \%$ count on the help of relatives/friends and/or selling personal goods or having savings, the rest picking other way outs such as: giving up working in the mining field, leaving the country to work abroad, reducing expenses with housing, meals or even revolution to abolish the current political leaders. The exact numbers per category of the 519 choices made are presented below in Table 3. 
Table 3: Solutions indicated by respondents to overcome the crisis (more than one choice /subject)

\begin{tabular}{|l|l|l|l|l|l|}
\hline Valid & Solutions & Frequency & Percent & $\begin{array}{l}\text { Valid } \\
\text { Percent }\end{array}$ & $\begin{array}{l}\text { Cumulative } \\
\text { Percent }\end{array}$ \\
\hline & Working more than one job & 268 & 51.64 & 51.64 & 51.64 \\
\hline & Use personal savings & 113 & 21.77 & 21.77 & 73.41 \\
\hline & Help from relatives/ friends & 47 & 9.05 & 9.05 & 82.46 \\
\hline & Sell properties/goods & 46 & 8.86 & 8.86 & 91.32 \\
\hline & $\begin{array}{l}\text { Save - create deposits } \\
\text { RON/other currencies }\end{array}$ & 42 & 8.10 & 8.10 & 99.42 \\
\hline & Other ways* & 3 & 0.58 & 0.58 & 100.00 \\
\hline & Total choices & 519 & 100.00 & 100.00 & \\
\hline
\end{tabular}

Source: authors

* giving up working in the mining field, leaving country to work abroad, reducing expenses with housing, meals or even revolution to abolish current political leaders

Still on the topic of finding ways to overcome the crisis effects, we asked another question touching the institutional level. Hence, subjects were asked about who should play a major role in taking measures to overcome the crisis. The question had multiple answers, respondents being able to select more than one option. We gathered thus 747 options which means almost 2 for each respondent. It is the highest number we have got during this research; the result expresses the highest degree of interest of respondents in the topic.

Respondents distributed the responsibility of having to take measures to overcome the crisis to the Government first and then to the Parliament, Economy Ministry, N.H.C.C. management. The rest represented as "other" in figure 11 below is shared by: mining unions, mining company's management, the Presidency, the Romanian people- as entity with decision power:

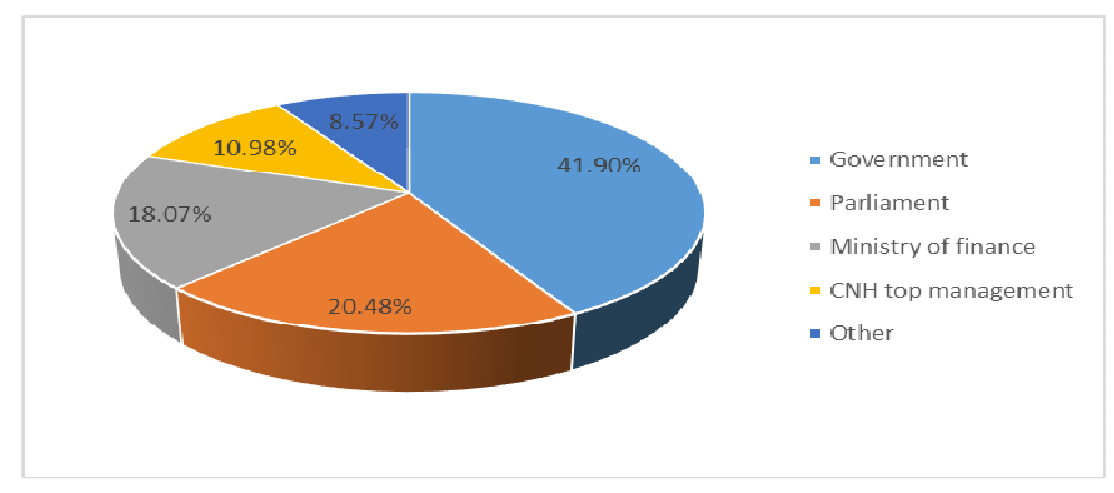

Figure 11: Institutions that should play a major role in taking measures to overcome the crisis

Source: authors

At the end of our research, we analyse the hypothesis with which we begun. Based on the gathered data - see correlation table 1we can state that the hypothesis that started this research is confirmed for the majority of the respondents, in the sense that the ones highly affected by the crisis are the ones who are very scared that they would lose their jobs. Also, the ones affected on a medium degree consider in an overwhelming ratio that they might lose their jobs - as shown below in figure 12 . 


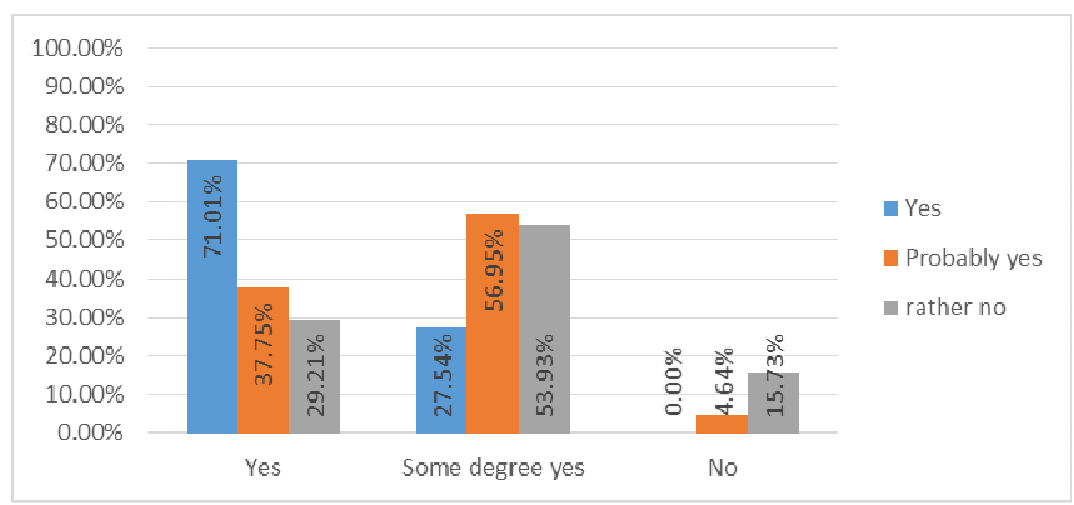

Figure 12: Link between the degree of the respondents affected by the crisis and their fear of losing their jobs

Source: authors

\section{Conclusions}

The present work was developed around the economical-financial crisis and how it affected the employees of the mining sector in Valea Jiului, specifically Uricani Mining. Face to face talks and data analysis revealed the respondents' worries not only for themselves but mainly for their families and their future. The lack of alternatives is number one worry as people go every day down in the mine knowing it is their only way to feed their children, and this reflects in every other life component influencing their mind, present and future alike.

The primary data analysis and the correlations we have made revealed interesting and sometimes surprising aspects on the subject. By far, the most important aspects are the number of people affected by the crisis and their fear about losing their jobs. Respondents look at the crisis and acknowledge it through the filter of their age, gender, education. The male respondents below 50 would adventure into looking for work anywhere else in the country or abroad, while women over 50 would only look for a job in the area. University graduates would also stay considering they have higher chances to find a new job at the expense of less educated unemployed people. With regard to the initial research hypothesis that was largely confirmed, the results demonstrate that people most affected by the crisis are also people more afraid they would lose their jobs.
The industry restructuring generated new problems so far, such as: fast economical drop of the mining regions, enhancement of social issues, poverty increase. Social problems in the area are mainly the result of a too long specialisation on just one economic activity, the heterogenic population, limited resources availability in the area to sustain further economic progress and slow and low adapting to change. It is obvious that no mining area should be shut off in such short time, hence the need for medium to long term strategies working on correlating as much as possible the industry with the environment strongly affected by it. Any strategy should consider all aspects: economic, social, governance, environment and put at its core people. It should consider involving people in implementing actions, in taking measures together with local authorities, NGOs in the true spirit of consistent and sound development.

\section{Acknowledgment}

" This paper was co-financed from the European Social Fund, through the Sectorial Operational Programme Human Resources Development 2007-2013, contract POSDRU/159/1.5/S/155463: "Supporting excellence in scientific interdisciplinary doctoral research in the economic, medical and social fields", coordinator The Bucharest University of Economic Studies". 


\section{References}

1. Bodea, I., Bozdog, A.F. and Burdea, F. (2013), Stresul, factor de risc important pentru sănătatea şi securitatea în muncă la minele din Valea Jiului, Paper presented at the Conference "Jubiliară a Inspecției Muncii, Securitate și Sănătate în Muncă", 2123 Octomber 2013, Sibiu, Romania.

2. Company Complexul Energetic Hunedoara S.A. Available from: <http://www.cenhd.ro>.[20 September 2015].

3. Marica, L., Irimie, S. and Băleanu, V. (2015), 'Aspects of Occupational Morbidity in the Mining Sector', Procedia Economics and Finance, 23, 146-151, [Online]. ScienceDirect, Elsevier. doi:10.1016/S22125671(15)00368-8, [Retrieved August 24, 2015],

http://www.sciencedirect.com/science/arti cle/pii/S2212567115003688
4. Ministry of Labor, Family and Social Protection. Available from: <http://www.mmuncii.ro>.[23 June 2015].

5. Preotesi, M., (2014), "Economic and social policies impacting on the social underdevelopment - case study: mining restructuring in Valea Jiului", European Journal of Social Sciences Education and Research, 1 (1), 209-216. [Online], [Retrieved September 12, 2015], http://ejser.euser.org/issues/may-aug2014/MihneaP...pdf

6. Stegar, I. (2014) The Disaster Programmed of Jiu Valley, Focus Publishing, Petroșani.

7. Stegar, I. and Krausz, S. (2011), Reacţia angajaţilor Companiei Naţionale a Huilei la pericolul pierderii locului de muncă, Paper presented at the National Conference „Sociologia şi Asistenţa Socială în faţa provocărilor crizei", 23-24 September 2011, Bucharest, Romania. 